\title{
THE SOUNDSCAPE OF JUSTICE
}

\author{
James Parker ${ }^{*}$
}

\begin{abstract}
Sound is a fact of life. But it is not a fact that contemporary legal thought has made any particular efforts to acknowledge, let alone to interrogate in any depth. As a community of jurists, we have become deaf to law and to the problem of the acoustic. We must begin to take responsibility for a dimension of legal experience that is no less real or significant simply because we barely attend to it. We need to begin to imagine a specifically acoustic jurisprudence. This article is a first step in that direction. By means of a close study of the 'soundscape of justice' at the International Criminal Tribunal for Rwanda, and specifically in relation to the case of Simon Bikindi, who was accused by the Tribunal of inciting genocide with his songs, it aims to convince readers that the question of sound is worth attending to, that it bears an important relation to questions of justice and that it is very much capable of influencing institutional outcomes. Sound, after all, is a condition of the administration of justice, an inalienable part of our legal worlds.
\end{abstract}

In the same building in which Bob Dylan recorded much of his seminal album Blood on the Tracks, ${ }^{1}$ there is a room within a room within a room. The outermost of these is lined with foot-thick concrete, the inner two have double walls of insulated steel. The central cavity floats on I-beams and springs and is lined with fibreglass acoustic wedges more than 3 feet thick. This is the anechoic chamber at Orfield Laboratories in southern Minnesota. With background noise levels at $-9.4 \mathrm{dBA}$ (nine point four decibels below the normal range of human audition), it is officially the quietest place on earth. ${ }^{2}$ If you were to spend any time in it, however, you would probably be surprised by what you heard. 'The total absence of sound outside your body', Patricia Kelly explains, 'makes you keenly aware of what's going on inside your body.' Your heart pumps. Your lungs inflate and deflate. Your ears buzz. Your blood pulses audibly. In an anechoic chamber, 'you are one

$\mathrm{PhD}$ candidate at Melbourne Law School. My sincerest thanks to my supervisors Shaun McVeigh and Andrew Kenyon for their continuing support and guidance. I would also like to thank Olivia Barr, Karen Crawley, Luis Eslava and Rebecca Goodbourn for reading and responding to this article in at least one of its various early forms. All errors, of course, remain entirely my own.

Dylan (1975).

According to The Guinness Book of Records. See www.guinnessworldrecords.com/ Search/Details/Quietest-place/59374.htm. Unofficially, the anechoic chamber at the University of Salford in Manchester is quieter, with a background noise level of 12.4dBA. See www.acoustics.salford.ac.uk/facilities/index.php?content=anechoic. 
noisy organism' ${ }^{3}$ Following his own experience in a similar chamber in the 1950s, American composer John Cage put it like this. 'Try as we may to make a silence,' he wrote, 'we cannot. ${ }^{4}$ Sound, it seems, is a fact of life.

It is not a fact, however, that contemporary legal thought has made any particular efforts to acknowledge, let alone to interrogate in any depth. Jurists never tire, it seems, of proclaiming law's specifically scriptural qualities, or its alleged privileging of sight. ${ }^{5}$ We live, apparently, in a 'visual culture'. And 'in a visual culture law, too, operates visually'. ${ }^{6}$ Maybe so although there is good reason to treat such totalising claims with a healthy dose of scepticism. ${ }^{7}$ Whether or not one accepts the proposition that law in the West is fundamentally ocularcentric, however, the specifically auditory dimensions of legal experience and practice are surely worth considering anyway. If life and law necessarily are lived in sound, we would do well to pay attention.

The stakes, after all, are high. Law 'is never just a mental or spiritual act'. It exists 'only to the extent that there are commitments that place bodies on the line, ${ }^{, 8}$ and it takes place, as Robert Cover has famously argued, 'in a field of pain and death'. 'As jurists, we are not separate from all this. 'The violence which judges deploy necessarily engages anyone who interprets the law in a course of conduct that entails either the perpetration or the suffering of this violence. ${ }^{10}$ The question of justice is therefore always also a question of responsibility. As a community of jurists, we must begin to take responsibility for a dimension of legal experience which is no less real or significant simply because we barely attend to it. We need to begin to imagine a specifically acoustic jurisprudence.

This article is a first step in that direction. The task of delineating such a jurisprudence is a large and difficult one, and not something I will be

\section{Kelly (2008).}

Cage (1968), p 8.

5 On law's textuality, for example, see Goodrich (1990); Vismann (2008). And on the relation between law and visuality, representative texts include Sherwin (2011); Goodrich (2001); Bently and Flynn (1996), pp 1-21.

6 Sherwin (2011), p 2.

7 For Alan Burdick, 'the golden age of the ear never ended. It continues, occluded by the visual hegemony.' And for Sterne, 'there has always been a heady audacity to the claim that vision is the social chart of modernity'. 'There is not doubt,' he writes, 'that the philosophical literature of the Enlightenment - as well as many people's everyday language - is littered with light and sight metaphors for truth and understanding. But, even if sight is in some ways the privileged sense in European philosophical discourse since the Enlightenment, it is fallacious to think that sight alone or in its supposed difference from hearing explains modernity.' Or, for that matter, law. See Burdick (2001), p 75; Sterne (2005), p 3.

$8 \quad$ Cover (1986), p 1605.

9 Cover (1986), p 1601.

10 Cover (1986), p 1601, n 1. 
attempting here. ${ }^{11}$ I will say this however: an acoustic jurisprudence would be concerned with how law is lived, both in sound and by virtue of it. It would address the ways in which legal thought and practice have both attended to the question of sound on the one hand, and neglected it on the other. It would be interested too in the relationship between audition and the other senses: in how they interact and fail to, and whether claims about law's privileging of one over the others are indeed borne out. Thematically, an acoustic jurisprudence would be concerned both with more familiar juridical topics such as the relations between speech, authority, jurisdiction and reason, and less familiar ones such as music, song, voice and affect. It would address the acoustic dimensions of legal technologies and architecture, as well as the notions of both hearing and listening. And it would be concerned with these questions, moreover, in their metaphysical as well their material or phenomenological dimensions.

Too much to cover here, in other words. In terms of exposition, the aims of this article are more modest. At the level of performance, however, it does attempt to do something important. Rather than furnish a complete account of what an acoustic jurisprudence entails, it is illustrative and episodic. It aims to convince the reader by demonstration as much as argument that the question of sound is worth attending to, that it bears an important relation to questions of justice, and that it is very much capable of influencing institutional outcomes. If this article had a grammar, in other words, it would be the imperative. It is an appeal to jurists: to pay attention; to listen better; to prick up your juridical ears! ${ }^{12}$ Sound, after all, is a condition of the administration of justice, an inalienable part of our legal worlds.

To be more specific, this article is concerned with what I am calling the 'soundscape of justice'. The term 'soundscape' will be unfamiliar to many jurists. It was first coined by R Murray Schafer in a series of booklets and articles around 30 years ago, which were then soon followed by his more famous book-length treatment The Soundscape: Our Sonic Environment and the Tuning of the World in 1976. ${ }^{13}$ Therein Schafer offered the following definition. The soundscape, he said, was our sonic environment, or 'technically, any portion of the sonic environment regarded as a field for study. ${ }^{14}$ While such a definition certainly has the advantage of succinctness, following Alain Corbin and Emily Thompson I use the term slightly differently here to incorporate not just the Tribunal's acoustic environment itself, but also the way in which that environment is constructed, understood and perceived. ${ }^{15}$ 'Like a landscape,' writes Thompson, 'a soundscape is simultaneously a physical environment and a way of perceiving that

For a more complete account, see Parker (forthcoming).

Douzinas (2007), p 31; Nancy (2007), p 3.

Schafer (1968, 1971, 1973, 1976).

Schafer (1976), p 274.

See Corbin (1994), p ix; Thompson (2004), p 1. 
environment; it is both a world and a culture constructed to make sense of that world.' It is a combination both of the sounds themselves and the set of listening practices developed to make sense of them, of the acoustic ecology and what Jonathan Sterne has termed 'audile technique'. ${ }^{16}$ As Thompson explains:

[T] he physical aspects of a soundscape consists not only of the sounds themselves, the waves of acoustical energy permeating the atmosphere in which people live, but also the material objects that create, and sometimes destroy, those sounds. A soundscape's cultural aspects incorporate scientific and aesthetic ways of listening, a listener's relationship to their environment, and the social circumstances that dictate who gets to hear what. ${ }^{17}$

For Thompson, a soundscape ultimately 'has more to do with civilization than with nature', and as such it is constantly under construction, always undergoing change. ${ }^{18}$ In law especially, these changes matter.

The study of a soundscape always begins with the particular: a place and a time, a building, a city, an institution. In what follows, we will be concerned with one particular institution and one particular case. The institution in question is the International Criminal Tribunal for Rwanda (the ICTR), and the case is that of Simon Bikindi. ${ }^{19}$ In many respects, both are utterly typical in legal terms. Much of what follows, therefore, will have obvious resonances whatever one's jurisdictional background or particular field of research. In certain other respects, however, both examples are quite unusual. And they are unusual in ways that make them particularly rich from the perspective of an acoustic jurisprudence.

As far as the Bikindi case is concerned, this richness is the result of the unusual centrality that it gave to the question of music. Between September 2006 and December 2008, Bikindi stood trial at the ICTR accused of committing six serious violations of international law: (1) conspiracy to

16 Sterne uses the term 'audile technique' to denote, as he puts it, 'a concrete set of limited and related practices of listening and practical orientations toward listening'. In doing so, he means to invoke both the French sociologist Marcell Mauss's notion of 'techniques of the body' and the more overtly philosophical tradition in relation to techne which begins with the likes of Aristotle and culminates more recently in the work of Martin Heidegger, Jacques Ellul, Jacques Derrida and Bernard Stiegler, amongst others. For Sterne, technique 'connotes practice, virtuosity, and the possibility of failure and accident, as in a musician's technique with a musical instrument. It is a learned skill, a set of repeatable activities within a limited number of framed contexts.' Moreover, it has both a conscious and an unconscious element: it is a product both of will and what Pierre Bourdieu calls 'habitus' - that is, a form of 'socially conditioned subjectivity'. For a detailed account of audile technique, see Sterne (2005), pp 92-95. See also Mauss (1979); Aristotle (1962); Heidegger (1977); Ellul (1964); Derrida (1989); Stiegler (1998).

17 Thompson (2004), pp 1-2.

18 Thompson (2004), pp 1-2.

19 Prosecutor $v$ Bikindi (Judgment) (International Criminal Tribunal for Rwanda), Trial Chamber III, Case No. ICTR-01-72-T, 2 December 2008. 
commit genocide; (2) genocide or, alternatively, (3) complicity in genocide; (4) direct and public incitement to commit genocide; (5) murder as a crime against humanity; and (6) persecution as a crime against humanity. ${ }^{20}$ There was never any doubt, however, that first and foremost it was a musician on trial. Donald MacNeil, a journalist for the New York Times, put it like this:

Simon Bikindi is Rwanda's most famous musician, but he is also one of the country's most famous accused war criminals ... The 'statement of facts' in his six-count indictment runs to forty-six paragraphs, but the charges against him focus on his music: in essence, Bikindi is accused of inciting genocide with his songs. ${ }^{21}$

That is, although the case against Bikindi was undeniably about more than just his songs on paper, in one way or another music was at its core. Whatever Bikindi's intentions may have been as his songs' author, the fact remains that they were sung literally as the perpetrators of Rwanda's genocide 'hacked or beat to death hundreds of Tutsis with government issued machetes and homemade nail-studded clubs'. ${ }^{22}$ 'Members of the population knew [his songs] by heart,' testified one witness at trial, 'and when they perpetrated those crimes, they would sing his songs, and say that they were furious and wanted to avenge the deaths of their relatives. ${ }^{23}$ What all this meant when it came to trial was that Bikindi's songs assumed a central position to the case in both substantive and formal terms. As one judge pithily observed, Bikindi's was a 'musical trial' ${ }^{24}$ As well as being the topic of mountains of official paperwork and hours of discussion at trial, music featured regularly as part of the trial's 'soundscape'. Audio and audiovideo recordings of his songs were played regularly throughout. Witnesses, including Bikindi himself, frequently sang - both of their own accord and at the specific request of the Tribunal.

In what follows, I have left the question of Bikindi's music almost entirely to one side..$^{25}$ But that does not mean it is unimportant: it provides an important backdrop to what follows. It serves as a reminder of just how high the stakes can be where sound is concerned. It was not just Bikindi's own body 'on the line' after all. ${ }^{26}$ The court was being asked to adjudicate in Chamber III, Case No. ICTR-01-72-T, 2 December 2008, p 1.

21

MacNeil (2002).

MacNeil (2002). Chamber III, Case No. ICTR-01-72-T, 2 December 2008, pp 60-61.

T, 4 November 2007, p 35.

Again, I have dealt with it at length in Parker (forthcoming).

Prosecutor v Bikindi (Judgment) (International Criminal Tribunal for Rwanda), Trial

Bikindi was eventually convicted of incitement to genocide, though crucially not in respect of his songs. Instead his conviction was founded on some things he had said at a road-block one day in June 1994. He was sentenced to fifteen years' imprisonment with credit for the seven years he had already served. See Prosecutor v Bikindi (Judgment) 
relation to a genocide in which many more than 500,000 people were killed and in which a question of sound was directly implicated: music, as composer Edgard Varèse famously put it, is at root 'organized sound' - no more, no less. ${ }^{27}$ Both in and out of the courtroom, in other words, what the trial of Simon Bikindi suggests is that the use and abuse of sound is capable of having real, determinate and potentially severe consequences.

Although this article takes many of its examples from the Bikindi case, its main focus is the Tribunal itself. I said above that as an institution the ICTR is particularly rich from the perspective of an acoustic jurisprudence. This is because of how central audio-technologies are to the conduct of judicial proceedings there. In addition to more general matters, the role of such technologies in juridical practice is precisely one of the main concerns discussed below. It is also such technologies, moreover, that make work such as mine possible for the first time. I was particularly fortunate that the ICTR's chief audio-visual archivist Martha Hunt agreed to use the Bikindi case in the Judicial Record and Archive Unit's pilot program as the Unit began to develop its archival methodology at the start of November 2009. Over the next few years, the Tribunal will make public a complete and redacted audio and audio-visual archive for every case it has heard. And when it does, it will be among the first legal institutions in the world to do so. What follows is based significantly on the audio-archive in the Bikindi case, but it derives too from a complete set of redacted transcripts on the one hand, and observations made during a month-long stay at the Tribunal in January 2011 on the other, nearly three years after Bikindi's trial had ended.

This article is divided into four sections. It begins with the soundscape of Arusha itself, the city in which the ICTR is found. It works from there through the soundscape of the Tribunal in broad terms to that of the courtroom specifically. We will see how soundproofing has become a condition of international juridical practice and how the 'keynote sounds' at the ICTR speak of an institution that operates by means of a phenomenological dislocation from the particularities of time and place. We will notice how, at least in the international context, the courtroom has become increasingly compartmentalised in acoustic terms, such that the word 'courtroom' itself is practically misleading. With each one comprising six discrete and acoustically separate spaces, headphones are now virtually a condition of participation, an essential portal into the trial's acoustic world.

I will then consider some of the implications of the wiring of the courtroom for sound: how the experience of listening through headphones, for instance, produces an increasingly individuated, cellular and bureaucratic listening practice; and how participants must learn to 'play' their microphones effectively in order to make themselves heard. Audiotechnologies do not simply record and reproduce the sounds of the juridical environment: they change them.

(International Criminal Tribunal for Rwanda), Trial Chamber III, Case No. ICTR-01-72T, 2 December 2008, p 112. 
In the next section, I turn briefly to the question of the gavel and to the judge's role in policing the soundscape. This is not unconnected from the question of technology, as we will see. As well as possessing specific acoustic properties, the gavel is an important symbol of the judge's right to speak and to determine who speaks, an index of their authority to decide. At the ICTR, the particular form of authority both symbolised and enacted by means of the gavel is increasingly being extended by a judiciary which is ever more savvy in technological terms.

Finally, we come to the history and practice of 'simultaneous interpretation'. Simultaneous interpretation is both the child of international law, borne of specifically legal concerns in a specifically legal setting, and integral to its ongoing success. Not only was it responsible for having introduced many of the audio-technologies we see today at the ICTR to the juridical context, but its consequences for the tempo, rhythm and accent of justice have been considerable. It is no exaggeration to say that simultaneous interpretation has been one of the most important factors in shaping the soundscape of international justice today.

\section{The Soundscape: Arusha}

Home to the Waarusha people prior to German colonisation at the end of the nineteenth century, Arusha is situated right at the foot of Mount Meru and on the easternmost edge of the Great Rift Valley, more or less equidistant from two of East Africa's most popular travel destinations, the Kilimanjaro and Serengeti National Parks. Today, along with Nairobi, it is one of the major hubs of tourism in the East African region. But it is a crucial legal and diplomatic centre too. On one side of town sits the African Court for Human and Peoples' Rights. ${ }^{28}$ On the other - just north-east of the city centre - is the Arusha International Conference Centre which, in addition to hosting a variety of international meetings year round, ${ }^{29}$ has provided a home to the International Criminal Tribunal for Rwanda since November $1995,{ }^{30}$ and a headquarters for the East African Community since its re-establishment in mid-2000 ${ }^{31}$ Much of this, moreover, is palpable at the level of acoustics, Arusha's very sound. The soundscape of the world, as Schafer argues, is not an 'indeterminate composition over which we have no control'. ${ }^{32} \mathrm{We}$ are its composers and performers.

The city centre in particular is constantly alive with an unmistakably cosmopolitan chatter. ${ }^{33}$ Swahili, Maasai, Meru, Rwa and a host of other

www.african-court.org/en.

www.aicc.co.tz.

First Annual Report of the International Criminal Tribunal for Rwanda (1996), p 5, http://unictr.org/tabid/117/default.aspx.

31 www.eac.int/about-eac/eac-history.html.

32 Schafer (1976), p 5.

33 I am conscious here of a certain form of rhetoric that casts Africa's urban soundscape as 'noisy' - in the derogatory sense of the word rather than the more descriptive sense 
languages local to the region intermingle with English and French - the languages of Africa's colonisation - but also countless other global accents and tongues. Street vendors attracted to the region by the city's burgeoning commerce hawk fruit, newspapers and safaris to anyone who will listen, as well as to many who would prefer not to. The low rumble of machinery and the high clang of metal upon metal signal the many new commercial building projects that are ongoing: hotels, particularly, but also office spaces. The drone of traffic is a constant. Wealth is inscribed directly here, at the level of mufflers and engine design. The luxury four-by-fours owned by rich locals and safari operators purr by quietly in violent contrast to the rumble and clatter of the many daladalas (mini-bus taxis) and pikipikis (motorbike taxis) that provide low-cost transport to everyone else. Drivers put their horns to extensive use, particularly after dark. With no street lighting to speak of and regular power cuts anyway, they announce, warn and aggravate late on into the night. And further away from the centre of town, as commercial and institutional life fades into the suburban sprawl, a different soundscape begins to emerge. Dogs, chickens and the abundant red-winged starlings are all audible now. And in the richer areas, so is the hum of generators. Music is everywhere. Bongo Flava - Tanzania's own particular fusion of American hip-hop and R\&B with traditional Tanzanian styles such as taarab and dansi - emanates from bars and radios. ${ }^{34}$ And then, on weekend mornings particularly, sacred music takes over, ${ }^{35}$ echoing out from the numerous churches on the city's periphery. Praise songs are performed rapturously in close harmony, sometimes simply a capella, sometimes over tinny backing tracks on battered and blown out public address systems.

employed, for example, by Jacques Attali in Noise: The Political Economy of Music where the word refers to sounds in general, including music - in contrast to the ostensibly orderly sounds of the West. An ostensible 'mastery' over the soundscape, on this view, is understood as a marker of development and progress. Indeed, it is quite possible that just such a racist logic is implicit at some level in the practice of international justice. I want to be absolutely clear, however, that this is not a view I endorse. My brief account of Arusha's soundscape here is intended to be descriptive, not critical. The point is simply to situate the Tribunal in its proper acoustic environment and to emphasise the fact that isolation from the immediate acoustic world is a condition of contemporary international justice mechanisms. This is not true, for instance, in many other juridical systems, most notably in this context Rwanda's Gacaca courts, which frequently take place outdoors. Indeed, the Western tradition offers many ancient and contemporary examples of its own. For a discussion of many of these examples, see Mulcahy (2010), Ch 2. For an excellent treatment of the Gacaca system, see Clark (2010). On 'noise', see Attali (1985); Thompson (2004).

For a detailed account of the taarab and dansi styles as well as their role in 'performing' the Tanzanian nation, see Askew (2002). The 'bongo' in Bongo Flava is not a reference to the Cuban percussion instrument. It is a slang term for Dar Es Salaam, Tanzania's capital and the place where the genre originated.

It is worth noting here that Bongo Flava often deals with religious themes in its lyrics. The strictness of the divide between sacred and secular music in Tanzania is not so pronounced as it is presently in many Western contexts. 
These are some of the sounds that both accompany and produce particular forms of daily life in Arusha. Anyone who has worked at the ICTR in recent years will be familiar with them. They are a few of the city's more obvious 'keynote sounds' - its 'signals' and its 'soundmarks' to adopt the Schaferian terminology. ${ }^{36}$ But as you enter the Conference Centre in which the Tribunal is housed, via the beep-beep-beeping of the x-ray equipment and the electronic gate as you pass through security, Arusha's acoustic particularity quickly begins to fade.

\section{The Soundscape: The Tribunal}

This is the result of an architectural logic that - since 'noise' was first identified as a distinctive problem for modernity at the dawn of the Industrial Revolution - has increasingly made acoustics and the material conditions of sound-isolation one of its central concerns. ${ }^{37}$ In 1931, the editor of the American Architect, Benjamin Betts, expressed his hopes for the then burgeoning 'business of sound control' in an article entitled Is This Our Next New Big Business?: 'Through its power, outside noises can be shut out of offices and apartments.' 'The day is not far distant,' he predicted, 'when prospective buyers and tenants of buildings will ask, "Is it soundproof?", 38 Already in the early 1930s, as Emily Thompson argues, that day was at hand. ${ }^{39}$ Today, the business of architectural acoustics is both deeply and globally entrenched. Soundproofing is one of the material conditions of international juridical practice.

At the Arusha Conference Centre, thick concrete walls block all but the most obstinate traffic noise and the twittering of birds perched on windowsills. Linguistic variety diminishes as conversations converge upon French and English, the two official operational languages of the United Nations. And the constant hum of strip-lighting, air conditioning units and computer fans provides the keynote sounds now, anchoring those who work at the Tribunal in a very particular kind of institutional space and mode of life. Even though these sounds may not always be heard consciously, even though one is able to learn not to listen to them, 'the fact that they are ubiquitously there', as Schafer argues, 'suggests the possibility of a deep and pervasive influence on our behaviour and moods'. The keynote sounds of a given place are important because they 'help to outline the character' of the men and women living among them. ${ }^{40}$ In the ICTR's case, these sounds speak both of a financial situation considered appropriate to the workings of contemporary international justice mechanisms and a form of bureaucratic and technological efficiency that operates precisely by means of a

Schafer (1976), pp 9-10.

37 For a history of 'noise and modern culture' in America at the turn of the twentieth century, see Thompson (2004), pp 115-57.

38 Betts (1931), p 21.

39 Thompson (2004), p 175.

$40 \quad$ Schafer, (1976), p 9. 
dislocation from the immediate vicissitudes of time and place. Inside the walls of the Tribunal, Arusha's choking summer heat, its civic hubbub and even the waning light are of very little consequence. ${ }^{41}$ Life and more importantly work, the day-to-day business of justice, goes on regardless.

\section{The Soundscape: The Courtroom}

From an acoustic perspective, the courtrooms themselves are undoubtedly the Tribunal's most carefully regulated spaces. This is true both in material terms, at the level of architecture and technology - soundproofing and wiring - and in social terms, at the level of behaviour - institutional habitus. ${ }^{42}$ At the time of writing, three courtrooms continue to be operational. A fourth was established temporarily by means of a grant provided by the Norwegian government in 1999 in order to help ease the Tribunal's increasing backlog of cases. Today it lies dormant. Chairs pile on tables and all is quiet, both inside and out. The active courtrooms, by contrast, are a hive of sound and industry. This much is clear even from the outside: from the brisk tip-tapping of footsteps along the concrete corridors, the discrete but urgent whispers at doorways and the occasional throbbing of photocopiers in the hallway. A document, perhaps, is urgently needed in court.

Inside, it turns out that the word 'courtroom' is actually something of a misnomer. Each room comprises six discrete and relatively well soundproofed spaces, rather than being a single open room. First, and most obviously, there is the central chamber where the defendant, judges and lawyers sit along with various administrative personnel for the Registry and witnesses whenever they are called. This is a slim, low-ceilinged rectangular room, walled with concrete on one side behind the judges' bench and bulletproof glass on the three others. The tables are lined with microphones and video monitors, and scattered with headphones, and the long wall opens on to the public 'gallery', which unlike in many domestic courts in the West is both physically and acoustically separated from the central judicial space. If one sits right up against the glass, it is just about possible to make out the murmur of conversation on the other side. But otherwise it is necessary to 'tune in' via an infrared receiver and headphones, which will have been handed to you by the security guard at the gallery's entrance when you signed in and checked your bag and your mobile phone. On one short wall, behind counsel for the prosecution, are the three interpretation booths: one for the English, one for the French and one for the Kinyarwanda interpreters. Again, each booth is acoustically separate from the central space, but this time, as in the main chamber itself, they are equipped with microphones for the transmission as well as headphones for the reception of audio signals. Finally, on the other short wall, behind counsel for the defence, is the audio-

\footnotetext{
41 The Tribunal keeps relentlessly to the UN timetable and calendar. Work starts at $8.30 \mathrm{am}$ sharp and continues to $5.00 \mathrm{pm}$ all year round, except on Fridays when the day finishes at noon.

42 Bourdieu (1990), pp 52-65; Bourdieu and Wacquant (1992), pp 13-14, 120-40.
} 
visual booth from where the soundscapes and videoscapes of the rest are monitored and controlled.

What does it sound like here, inside a 'courtroom' at the ICTR? Clearly there is an extent to which the answer to that question depends on who you are and which rooms you have access to. The soundscape of the central chamber, for instance, is utterly different to that in the public gallery or any of the four booths. Sit in the gallery during a hearing with your eyes closed and your headphones by your side and you will be hard pushed to recognise your surroundings as legal at all. You will hear that familiar humming of the strip lighting and air-conditioning unit, the slamming of a door off in the distance perhaps, the stirring of one of the journalists sitting along from you, and the faint and vaguely ghostly whisper of voices leaking from his and other observers' headphones. And that's about it. From the gallery, as from the interpretation and audio-visual booths, headphones are your exclusive portal into the juridical world you see before you through the glass. While that is obviously not the case in the central chamber itself, everyone there wears headphones nevertheless. Indeed, headphones are quite literally a condition of participation in a trial at the ICTR, ${ }^{43}$ and as a result acoustic experience there has become radically personalised. From the perspective of an acoustic jurisprudence, one of the most interesting aspects of the soundscape at the ICTR is not so much what it sounds like, but the technical means by which you are required to listen. The obvious question, therefore, is this. What happens to the soundscape when the courtroom is "wired for sound'? $?^{44}$

\section{Wired for Sound: Listening Alone Together}

There are four audio-channels to choose from on the little black infrared receivers attached to your headset: one corresponding to each of the three languages in which the trial is operating; and one, referred to as the 'floor channel', which allows you to hear whatever is being picked up by the microphones in the central chamber regardless of the language being spoken or, indeed, whether or not anything is being said at all. ${ }^{45}$ Each and every

43 There is a sense in which headphones have become both a condition of participation in and symbolic of international order itself, the material signifier of a discursive field that is utterly reliant on the technics of simultaneous interpretation for its success. Browse the website of any major international organisation - be it the United Nations, NATO or the International Criminal Court - and it will not be very long before you stumble across a pair of headphones in a photograph. Obviously, this was not always the case. In reference to the first day of the Nuremberg trial in November 1945, Francesca Gaiba writes that the 'bizarre view of a courtroom full of people with earphones competed for media and public interest with the presence of Hermann Göring and Rudolf Hess. "One reporter thought it looked like a telephone exchange."' Gaiba (1998), p 59. This turn of phrase is borrowed from an edited collection on the role of soundreproduction technologies in global culture: see Greene and Porcello (2004). 
person present at the trial is not only able but actively required to organise their own listening experience. Headphones off or headphones on, volume up or down, English, French or Kinyarwanda: cocooned in their 'Cartesian headsets', ${ }^{46}$ participants in the juridical soundscape must both occupy and arrange their own private acoustic worlds.

What is interesting about the acoustic individuation at trial, however, is just how social it is. This is not the kind of headphone usage one sees on buses and trains, for instance. In such cases, the listening is specifically intended to produce a certain kind of isolation from the immediate social environment - a kind of cloistered or reclusive listening if you like. ${ }^{47}$ During a trial at the ICTR, although everyone present may be listening differently, they are nevertheless all listening together. Sound and media theorist Jonathan Sterne has captured the apparently paradoxical nature of this mode of listening nicely in his discussion of certain forms of the emergent 'headset culture' towards the end of the nineteenth century. ${ }^{48}$ In Sterne's terms, the experience of listening to a trial at the ICTR is 'highly individuated, standardized, yet also collectivized' ${ }^{49}$ Participants, that is, must listen 'alone together'.$^{50}$ Their isolation is collective. ${ }^{51}$ What that means in practice is that listening at trial is frequently understood as a collaborative enterprise. Judges share tips with lawyers and, most frequently, with witnesses who are unaccustomed to the peculiar listening practices that participation in a trial at the ICTR requires.

But the (collective) individuation of acoustic space at trial produces another important aesthetic effect. 'Transmitted through air,' Sean Cubitt explains, 'sound occupies and creates an environment.' This is the sound of the traditional 'cavernous court', as Desmond Manderson has termed it $^{52}-$ London's historically high-ceilinged Old Bailey perhaps, or the International Court of Justice's so-called Great Hall at the Peace Palace in the Hague ${ }^{53}-$ where the resonance of the space, in collaboration with the scale of the

$46 \quad$ Cubitt (1998), p 104.

47 For an ethnography of contemporary personal stereo usage, see generally Bull (2000). Regarding the more reclusive aspects of headphone usage, Bull writes: 'Personal stereo use reorientates and re-spatializes the users' experience, with users often describing the experience in solipsistic and aesthetic terms. Personal stereos appear to provide an invisible shell for the user within which the boundaries of both cognitive and physical space become reformulated.' Bull (2000), p 31.

Sterne (2005), p 154.

$49 \quad$ Sterne (2005), p 165.

$50 \quad$ Sterne (2005), p 163.

$51 \quad$ Sterne (2005), p 161.

52 'A grand cathedral and a cavernous court,' he writes, 'the echoing of a Gregorian chant and the resounding clamour of a gavel ... For millennia we have been summoned to obey through our senses.' Manderson (2000), p 42.

53 For a small number of pictures of these two courtrooms, see www.oldbaileyonline.org/static/The-old-bailey.jsp\#courtroom; www.vredespaleis.n1/default.asp?pid=65\&page=Great_Hall_of_Justice. 
architecture that is required to produce it, communicates its very pomp and seriousness: one might even be tempted to say its 'aura'. ${ }^{54}$ In acoustic terms, the similarity to a church or other sacred location is unmistakable. Speech, songs and gavels resound and echo. Sound surrounds and envelops you. Not only are the courtrooms at the ICTR constructed specifically to muffle sounds rather than to let them resonate; headphones produce a completely different kind of listening experience. 'Transmitted directly to the ear with whatever purity of reproduction, [acoustic] space is reduced to an optimal (and imaginary) point midway between the ears. ${ }^{55}$ The moment you put on headphones, architectural becomes punctual space. Experienced both through headphones at the ICTR and via the audio-record at home, the courtroom sounds far more bureaucratic than sacred. It is less cavernous, more cellular.

\section{Wired for Sound: The 'Phonograph Effect'}

If these are some of the general effects produced by the introduction of sound-reproduction technologies into the juridical environment, there are many specific ones too. One thing that is abundantly clear from the transcripts and audio-record in the Bikindi case as well as from my own observations of ongoing trials is that headsets and microphones are never very far from the forefront of people's minds. These are mediators that clearly do not 'vanish' in the act of mediation. ${ }^{56}$ At the mundane level, participants are constantly fiddling with their headsets, switching between audio-channels and complaining about technical hitches. Episodes such as the following were not at all uncommon during the Bikindi case:

MADAM PRESIDENT: There is an - wait a minute, Mr Witness. There is an interference from the interpreter's booth. I don't know if the technicians can improve on that.

MR MORLEY: (Microphones overlapping) ${ }^{57}$... Your Honours, there is no interference in my headphones. I know not if there is a problem at the other end of the Court.

$54 \quad$ Benjamin (1968).

55 Cubitt (1998), p 103.

56 The phrase 'vanishing mediator' originally appears in Frederick Jameson's work, but has been picked up more recently in the work of Slavoj Žižek to refer to the fourth movement in Hegel's dialectic where, as Sterne puts it, 'the mediating term disappears, leaving its structure and effect but not its form'. Here, I use the term in the same sense intended by Sterne in relation to his cultural history of sound reproduction - that is, to refer to the kind of 'pure' mediation imagined by a certain kind of media theory and which is most often deployed as a marketing device. This kind of approach likes to imagine a mediator between 'original' and 'copy', which would render itself completely transparent, as if it were not even there. Needless to say, this is a pipe dream. The mediator never vanishes, it simply affects the process of mediation differently. The crucial thing is to notice how. See Jameson (1988), pp 3-34; Žižek (1991), pp 179-88; Sterne (2005), particularly p 218.

This is a marking that occurs quite frequently in the transcripts, a constant reminder of the fragility of the courtroom's acoustic ecology and of all the collaboration and effort required to maintain it. 
MADAM PRESIDENT: We have interference, and so has Defence, I see from Mr Ngeze [sic] nodding. So you are privileged. ${ }^{58}$

Indeed, for the first several months of Bikindi's trial, immediately following the recitation of appearances, Presiding Judge Weinberg de Roca would habitually check with Bikindi that he was able to follow correctly on his headphones before commencing substantive proceedings:

MADAM PRESIDENT: Thank you very much. Appearances for the Defence, please?

MR NDERITU: Thank you, Your Honour. Wilfred Nderitu, counsel for Mr Bikindi, together with Mr Jean de Dieu Momo, co-counsel for Mr Bikindi.

MADAM PRESIDENT: Thank you very much. Mr Bikindi, your headphones are fine? Can you follow the proceedings? ${ }^{59}$

In this example, the headphones were functioning properly as it turned out, but Bikindi had forgotten to switch on his microphone.

Effective microphone usage is an ongoing struggle at the Tribunal, particularly - though far from exclusively - where untutored witnesses are concerned. ${ }^{60}$ It is not just that people forget to turn them on, and are therefore both inaudible and uninterpretable as a result; participants need to learn to 'play' their microphones properly, as the following examples demonstrate. Sometimes it is a question of efficiency: 'Mr Witness, don't switch your microphone off. Just leave it on. Then it is not a problem every time you have to answer. ${ }^{61}$ Sometimes proximity: 'Madam Witness, if you can please sit straight so that your mouth is nearer the microphone. ${ }^{62}$ And conversely, 'Madam President, if the witness could be advised to sit back from the microphone. He is breathing into the microphone. ${ }^{93}$ Sometimes it is a matter of volume: 'Please make sure that you speak loudly enough that it comes through on the earphones, right, madam?' ${ }^{64}$ Or again, 'Message to Madam President from the English booth. I do not believe she has her headphones on. Could the witness please be requested to speak clearly and loudly?' ${ }^{65}$ And on another occasion the reverse, 'Mr Witness, please speak more softly because if you answer in a loud voice, we cannot hear the interpretation. ${ }^{66}$

58 T, 19 February 2007, pp 9-10. For other examples see, for instance, T, 27 September 2006, p 2 and p 33; T, 3 October 2007, p 13.

59 T, 22 September 2006, p 1.

60 Even several years into the trial, Presiding Judge Weinberg de Roca needed to be reminded to switch her microphone on. T, 31 October 2007, p 37.

$61 \mathrm{~T}, 12$ October 2006, p 10.

62 T, 24 September 2007, p 7.

$63 \mathrm{~T}, 26$ September 2006, p 6.

64 T, 1 October 2007, p 47.

$65 \mathrm{~T}, 31$ October 2007, $\mathrm{p} 2$.

66 T, 5 October 2007, p 37. 
The website of the International Association of Conference Interpreters has this to say of what it calls 'microphone discipline':

Microphones tend to amplify not only the interpreter's voice, but also all of the sounds in the booth around him/her (rustling papers, doors opening and closing, colleagues' coughs, pens scratching on paper). Consequently, strict discipline is recommended ... in order to spare the audience's ears. ${ }^{67}$

What each of these examples evidences is the obvious fact that soundreproduction technologies do more than simply record and reproduce the sounds of the juridical environment. They change them. They alter how people at the ICTR act, speak and, occasionally, sing. ${ }^{68}$

Mark Katz, in his study of the effects of technology on music-making practices in the twentieth century, has referred to this phenomenon as the 'phonograph effect': that is, 'any observable manifestation of recording's influence'. ${ }^{69}$ He gives the example of 'crooning', the 'soft, restrained vocal style popular form the 1920s to the 1950s, heard in the singing of Rudy Vallee, Bing Crosby, Perry Como, and Frank Sinatra'. Crooning, Katz argues, was made possible 'only with the microphone':

because without amplification such singing would be expressively flat and nearly inaudible. Yet the technique achieved a remarkable effect. Crooning is akin to whispering, which under normal circumstances can be heard only when one is physically very close to the speaker; crooning thus provides a sense of intimacy between artist and audience, collapsing the technologically imposed distance that would seem to preclude such a relationship..$^{70}$

The practice of contemporary international criminal justice, it turns out, is a lot like crooning. It too was made possible only with the microphone. Like Bing Crosby and Frank Sinatra before them, every lawyer, judge and witness who wishes to participate in a trial at the ICTR must learn to use this instrument correctly. Jonathan Sterne puts it like this: 'Machines [do] not simply "capture" sounds that already existed in the world." As long as sound-reproduction technologies have existed, he says, people have always 'performed for the machines'. ${ }^{71}$ In law, it falls to the judge to conduct this performance.

www.aiic.net/glossary/default.cfm?ID=190.

68 At one point during the trial, Bikindi was invited to sing a song that he had composed in the aftermath of the genocide. Midway through, he stopped to complain that he was being put off by the interpretation he could hear on his headset. T, 31 October 2007, p 35.

Katz (2010), p 2.

Katz (2010), p 46.

Sterne (2005), p 235. 


\section{Policing the Soundscape: 'Silence' and the Gavel}

Legal institutions have always been careful about policing the juridical soundscape. The yellow signs that adorn the corridors outside the courtrooms at the ICTR are typical in this respect. 'SILENCE PLEASE!' they read, 'COURT IN SESSION': capitalised and with the exclamation mark. Red signs prohibit mobile phone usage, both in the courtrooms themselves and around them. ${ }^{72}$ Relative quiet, it seems, is at once a condition and a sign of the proper administration of justice. Along with various symbolic and spatial aspects of a courtroom's architecture and design, it works to limit and determine both the modes of comportment and the 'enunciative modalities' - to adopt the Foucauldian terminology ${ }^{73}$ - available at trial. ${ }^{74}$ Above all, a quiet space suggests an attitude of respect and deference to whoever it is - whether priest, actor, conductor or judge - that presumably has been authorised to breach the peace. This is why the gavel continues to be such an important object. Although at the ICTR it is used only infrequently, and even then mostly just to mark the adjournment of proceedings for the day, one can be found in every courtroom nevertheless.

There is a sense in which the gavel is an intensely practical device. Before it symbolises anything, it has certain acoustical properties which make it well suited for disrupting noise and attracting attention. A sharp rap or two on the hardwood sounding-block is normally sufficient to pierce through any unwanted hubbub. Today, though, the gavel's significance is unquestionably more symbolic than practical. Or, to put it another way, its significance is practical precisely because it is symbolic. What it symbolises is the judge's authority to determine who gets to speak, when and in what ways. Apart from the 'illocutionary' force of the judicial word, ${ }^{75}$ this is quite possibly the most significant power a judge yields at trial. It is not that it is necessarily crucial to the maintenance of orderly discourse. A court could, in principle, have an 'impartial' moderator of sorts, along the lines of the 'speaker' in the parliamentary system. But in practical and aesthetic terms, the fact that it chooses not to is important. The very fact that control over juridical discourse is invested in the judge in this way both signals and regularly underlines the totality of their authority at the level of performance: day in, day out, session after session, hearing after hearing. The gavel, then, is the acoustic equivalent of the judge's robes, or the raising

According to what is now an internationally accepted semiotics, yellow signifies a 'warning' whereas 'red' refers to a prohibition. Nametags on office doors at the Tribunal are mostly blue.

73 Foucault (1981), pp 50-56.

74 For an excellent account of the diverse ways in which architecture and courtroom design influence such 'enunciative modalities' (though, it should be noted, at a time previous to the wiring of courtrooms for sound and visuals), see Goodrich (1990), esp pp 188-93. See also Mulcahy (2010).

75 On the 'illocutionary' speech act and performative speech in general, see Austin (1985); Derrida (1988); Felman (2003), and in relation to law specifically, see in particular Cover (1986); Butler (1997). 
of their bench. It is a symbol of power, of the right to speak and determine who speaks, to decide who gets to hear what and when: an acoustic index, in other words, of the judge's authority to decide per se. Within the parameters of the material limits set by architecture and technology, the gavel invests control over the juridical soundscape exclusively in the office of the judge. Moreover, the fact that this control has been so successfully internalised by the legal institution that in practice judges rarely need to use their gavel at all does not render it any less potent - in fact, quite the opposite. The gavel's silence only serves to make the judge's authority over the soundscape all the more complete.

\section{Policing the Soundscape: Technological Delegation}

At the ICTR at least, judges are increasingly delegating their work in this respect to technology. ${ }^{76}$ At trial, lawyers, judges and witnesses regularly need to convey sensitive information without certain others present being able to hear. Prior to the wiring of the courtroom, the problem would most likely have been managed by whispering. And occasionally it still is:

MR GABAAKE: 'Mr Witness, listen. This gentleman works in my office, the one there. So whisper to him the address. He is part of the Prosecution, and then he will write it down, okay?

THE ENGLISH INTERPRETER: Madam President, could the microphones be switched off? ${ }^{77}$

But far more frequently, the presiding judge will simply ask the person they do not want to hear a particular passage of conversation to remove their headphones so that the relevant legal officials may converse in a language which that person does not understand. Unable to hear the interpretation, they will have been rendered deaf for juridical purposes. 'Perhaps if the witness might remove his headphones, please. I'm raising this without the witness being able to hear it, so that my learned friend may make any observations and Your Honours may reflect on it. ${ }^{178}$ Here, rather than asking the interpreter not to translate what is being said, the task is delegated to the audio-technology itself. Moreover, this is a practice that is reproduced constantly. From the second day of Bikindi's trial alone, for example, I counted no less than eight separate occasions on which witnesses were asked temporarily to remove their headphones. ${ }^{79}$ It was not atypical in this respect. Now, this may admittedly not be an especially breathtaking advance for contemporary juridical practice. But what it does evidence is an institution that has learned to be sensitive to the particularities of its acoustic ecology, and is able to develop specialised listening practices and techniques in

${ }_{76}$ For an excellent discussion of the logic of 'delegation', which is so often ascribed to sound-reproduction technologies, see Sterne (2005), Ch 1.

T, 12 October 2006, p 20.

T, 18 September 2006, p 44.

T, 19 September 2006, pp 9, 14, 18, 19, 29, 36, 40, 41. 
response. If the gavel symbolises the authority of the judge over the soundscape, then headphones increasingly are becoming their tools for exercising it.

\section{Simultaneous Interpretation: The Child of International Law}

By this point, it should be clear that the wiring of the courtrooms for sound accounts for many of the distinctive features of the juridical soundscape at the ICTR. I hope it is also clear that the reason they have been wired this way is to facilitate the system of so-called 'simultaneous interpretation', and that it is this system that makes dialogue across three languages at the Tribunal possible. It is time now to say a little more about simultaneous interpretation, its origins - which are steadfastly juridical - and its most important effects on the soundscape in the practice of international law.

The system of simultaneous interpretation employed by the ICTR today was crafted, according to Francesca Gaiba, 'by trial and error in an attic room of the Nuremberg Palace of Justice' ${ }^{80}$ This was in 1945, in preparation for the famous Nuremberg Trial at which 24 defendants (including Herman Göring and Rudolf Hess) were tried for war crimes by the victorious Allied powers in the immediate aftermath of World War II. Today, the trial is most often remembered for its influence on the then nascent norms of international humanitarian, criminal and human rights law, which would go on to be developed in a number of key treatises and conventions at the end of the 1940s. But it was crucial for another reason too, particularly if one is looking at it from the perspective of an acoustic jurisprudence. Nuremberg was the first trial ever to be conducted multilingually - that is in several languages at the same time (namely English, French, Russian and German). The multilingual trial has since become the standard mechanism of international justice, of course, but in 1945 it was unheard of: a completely novel juridical form. And the system that made it feasible, by means of a marriage between recent technological developments and an established but exceptionally difficult form of interpretative practice, is quite possibly the unsung hero of international justice, especially in technical or material terms. It is not just that without it 'the Nuremberg Trial would not have been possible ${ }^{81}$ as Francesca Gaiba puts it in her fine account of simultaneous interpretation's history. None of the tribunals established to mete out international justice since then would have been possible either - including the ICTR.

In 1945, interpretation was nothing new. It had been around since Babel. It was only in the twentieth century, however, that it was professionalised following the abandonment of French as the lingua franca of European diplomacy at the Paris Peace Conference in 1920 and the subsequent founding of the first School for Interpretation in Geneva in

\footnotetext{
$80 \quad$ Gaiba (1998), p 11.

81 Gaiba (1998), p 20.
} 
$1941 .^{82}$ At the numerous international conferences that followed on from World War I, two primary techniques were used. The first and most common was so called 'consecutive interpretation'. With this method, the interpreter takes notes during the delivery of a speech and the speaker stops either at the end of every sentence or every section, depending on what has been agreed, so that the interpreter can reformulate what they have heard in the target language by reading back from their notes. The second method is known as 'whispered interpretation'. Here, the interpreter sits next to the person who does not understand the working language and whispers the translation into their ear while the speech is actually ongoing. The problem in the first case is that it makes proceedings excruciatingly slow. The problem in the second case is that it is intrusive, noisy and only really workable on a very small scale. ${ }^{83}$ When it came to preparing for Nuremberg, therefore, the International Military Tribunal found itself in a bind. On the one hand, its enabling charter granted defendants the right to a fair trial, one requirement of which, according to Articles 16 and 25, was that proceedings be comprehensible to them in their native tongue - which in this case was German. ${ }^{84}$ On the other hand, Articles 18 and 19 also sought to guarantee that the trial be carried out as quickly as practically possible. Defendants were granted the right to justice at a reasonable tempo.

'In order to reduce costs and time, and to keep the attention of the public and the media', ${ }^{85}$ the trial had not only to be 'just', but 'expeditious' too. According to Article 18, the Tribunal would be confined 'strictly to an expeditious hearing of the cases raised by the charges' and was required to 'take strict measures to prevent any action which will cause reasonable delay' ${ }^{86}$ According to Article 19, it would not be bound by the 'technical rules of evidence' and should 'adopt and apply to the greatest possible extent expeditious and nontechnical procedure' ${ }^{87}$ Today, proceedings at the ICTR must be both 'fair' and 'expeditious' too ${ }^{88}$ Consecutive interpretation may

82 The British insisted that English be recognised as an official diplomatic language, creating a permanent need for oral interpretation from that point forward. Today, the two official operational languages of the United Nations are still French and English only.

Today, the International Association of Conference Interpreters says the following about the whispering method: 'Whispering is not recommended when there are more than two listeners or when several interpreters need to work at the same time in the same room (since this could create too much noise and is as unpleasant for the interpreters as for the audience). A team working in this mode requires at least two interpreters. Since this technique is hard on the vocal chords, it is only appropriate for very short meetings.' www.aiic.net/glossary/default.cfm?ID=106.

84 Charter of the International Military Tribunal (1945), Art 16; Art 25.

85 Gaiba (1998), p 32.

86 Charter of the International Military Tribunal (1945), art 18.

87 Charter of the International Military Tribunal (1945), art 19.

88 This requirement appears in Article 19(1) of the Tribunal's Statute as follows: 'The Trial Chambers shall ensure that a trial is fair and expeditious and that proceedings are conducted in accordance with the rules of procedure and evidence, with full respect for the 
have worked well enough for long diplomatic speeches at large conferences, but the relatively quick-fire dialogue of legal discourse would be a different matter entirely. A system was needed that would maintain something of the 'spontaneity and rapidity' of legal questioning. ${ }^{89}$ And because whispered interpretation was obviously unworkable on the requisite scale, the only available solutions were to conduct proceedings solely in German or to come up with a better system. Given that a German trial was both politically and practically unworkable - it would be impossible to find both judges and prosecutors from each of the four countries responsible for conducting the trial who were both competent enough legally and sufficiently fluent in German - clearly some less intrusive and more efficient method needed to be devised.

By the end of the war, the technology required for simultaneous interpretation - the system of microphones, headsets and the ability to switch between several audio channels - had actually been available for some time in the form of IBM's Hush-a-Phone system. ${ }^{90}$ Prior to Nuremberg, however, it had only ever been used for a variant of the consecutive method known as 'simultaneous successive interpretation', where the interpretations were simultaneous with each other, but not with the original speech. According to Gaiba:

At the League of Nations and the [International Labor Organisation], for example, the various interpreters would take notes on the original speech, as for [normal] consecutive interpretation; after the end of the speech, one of the interpreters, usually the French interpreter, would take the stand and translate consecutively into his language. At the same time, the other interpreters, sitting in the booths and speaking into their microphones, gave their version of the speech in English, Spanish etc., reading from their notes. In this way, the translation was still consecutive and therefore fairly accurate, and the time required to translate into all languages greatly reduced, in comparison to the normal consecutive mode. ${ }^{91}$

For a trial, though, this system was still far too slow. In the end, it was Eisenhower's old interpreter, Colonel Léon Dostert, who convinced the Tribunal that the Hush-a-Phone system could be adapted for the purposes of

rights of the accused with due regard for the protection of victims and witnesses.' And on numerous occasions throughout the Rules of Procedure and Evidence. See Statute of the International Criminal Tribunal for Rwanda (1994); Rules of Procedure and Evidence (1995).

89 Gaiba, quoting simultaneous interpretation's inventor Colonel Léon Dostert. Gaiba (1998), p 101.

$90 \quad$ Not to be confused with the Hush-a-Phone device, which became the subject of a famous ruling in US telecommunications law. See Hush-A-Phone v United States, 238 F.2d 266 (DC Cir 1956). IBM's Hush-a-Phone was patented in 1926 and used for the first time in 1927 at the International Labor Conference in Geneva. See Gaiba (1998), pp 30-31. 
'spontaneous, immediate interpretation'.92 According to this system, the interpreter would speak at the same time as they were listening, as with the whispering method, but because they were speaking into microphones rather than to a pair of listeners at close quarters, a single interpreter would suffice for each language, so only twelve interpreters would be needed (see Figure 1)..$^{93}$

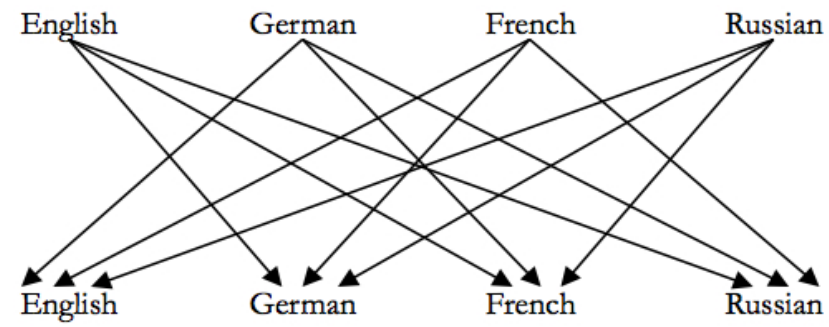

Figure 1: Interpretation at Nuremberg

When Colonel Dostert explained the system he was about to implement to the Tribunal's delegations from France, the Soviet Union and Great Britain, however, the reaction apparently 'swung between simple concern and overt scepticism'. Evidently, 'it seemed to them a task beyond human capabilities to hear and speak at the same time in different languages' ${ }^{94}$ And it is certainly difficult. On top of an excellent knowledge of both relevant languages, it requires an exceptionally refined 'audile technique', which in normal circumstances can take many years to acquire. It is a skill that even the best interpreters are not always able to master. All in all, more than 200 highly qualified interpreters were tested prior to the Nuremberg trial before the Tribunal's translation division was able to obtain the 36 simultaneous interpreters it needed in order to commence proceedings - that is, three teams of twelve. ${ }^{95}$ In general, they succeeded admirably, ${ }^{96}$ and particularly with so little time for preparation. ${ }^{97}$ The trial lasted more than ten months in

92 Gaiba (1998), p 35, quoting E Peter Uiberall, one of the interpreters who worked on the trial, in a letter to the author.

This system is known as the 'non-relay system'. The ICTR uses the 'relay system' instead, and therefore only requires three interpreters at any given time. I explain this system in detail below. See Figure 2 and corresponding text.

Gaiba (1998), p 37.

Gaiba (1998), p 48.

See Gaiba (1998), pp 95-131 for some of the difficulties encountered by the system.

While the interpreters at Nuremberg had just a few weeks, and in some cases a matter of days, to learn how to use the system effectively, the standard qualification takes a number of years to complete, depending on whether you study at undergraduate or masters level. See, for example, the list of programs currently available at Geneva's School of 
total and comprised 216 days in court - a long time by any standards. Without simultaneous interpretation, however, it would undoubtedly have lasted much, much longer ${ }^{98}$ Indeed, according to Evelyn Moggio-Ortiz, a member of the International Association of Conference Interpreters and producer of a film on the subject for the United Nations, ${ }^{99}$ the system apparently worked so well that Göring is said to have complained that it had cut his lifespan by three quarters. ${ }^{100}$

Though it is probably best known today as a commonplace at international meetings and conferences the world over, and particularly at the United Nations, simultaneous interpretation is indisputably the child of international law. It was conceived in a court, by a court and for specifically juridical reasons. First, the system arose partly as a simple matter of charter law. As long as the issue of interpretation was framed in terms of economic and temporal efficiency, the need to innovate was not felt sufficiently strongly to warrant the difficult step of training large numbers of interpreters to listen and speak at the same time. By making the tempo of judicial proceedings a matter of right, however, the Charter of the International Military Tribunal provided a different kind of impetus entirely. And it was the combination of this jurisprudential imperative with more material considerations that proved decisive in the end. Although the technology to implement the system had existed already for some 20 or so years, it was not until interpreters were confronted with the specifically legal soundscape the constant to-ing and fro-ing of legal discourse, complete with interruptions, objections and asides: the 'breathtaking rhythm' of examination as Gaiba eloquently terms $i^{101}$ - that the necessity for a completely novel interpretative method became clear.

\section{Simultaneous Interpretation: Justice Has a Tempo and a Rhythm}

Now that simultaneous interpretation has become so thoroughly embedded in the practice of international law, what impact has it had on the way international legal discourse actually sounds - and, correlatively, on the way in which legal actors are required to listen? Today, proceedings at the ICTR still move almost painfully slowly. The word 'simultaneous', it turns out, is misleading to say the least. Interpreters, obviously, must understand a minimum of information before they can begin their translation. The lag between the original and interpreted version is called décalage. It varies between interpreters, but it can easily be as much as about seven or eight seconds. What this means in practice is that everyone is constantly waiting

Translation and Interpretation, the contemporary iteration of the school founded in 1941 referred to above: www.unige.ch/eti/enseignements_en.html. On the training of interpreters at Nuremberg, see also Gaiba (1998), p 49. Gaiba (1998), p 11. Moggio-Ortiz (1995). See www.aiic.net/ViewPage.cfm/article1104.htm. www.unspecial.org/UNS678/t21.html.

101 Gaiba (1998), p 102. 
for the interpretation to filter through on their headphones before proceedings can move on. And as a result, the kind of speech patterns that emerge are incredibly fragmented. Simultaneous interpretation thus radically changes the nature of legal eloquence. Inside a courtroom at the Tribunal, speech has its own very particular tempo and rhythm.

'Every thought must have weight, every word must be impressive,' opined Cicero in On the Ideal Orator some 2000 years ago. 'To this must be joined a delivery that is varied, vehement, full or ardour and energy, full of real emotion.' ${ }^{102}$ Well not at the ICTR. Oratory at the ICTR sounds sluggish and fractured. It is slow and disjointed and is not at all easy to master. It requires an extraordinary amount of patience, both on the part of the person speaking and the listener. Judges and interpreters are constantly putting the breaks on speakers who lapse into their preferred metre. This sort of thing was absolutely typical at Bikindi's trial, for instance:

MADAM PRESIDENT: Mr Witness, please give us a short answer and speak more slowly. It's very difficult for the interpreters when you speak so quickly. So speak slowly, make pauses, and stop after giving a short answer so that Prosecution can tell you whether they want you to continue with what you are saying or want you to go in a different direction. Please answer the questions. Don't repeat what you want to say. But, first, listen to the question.

MS WRIGHT [assistant counsel for the prosecution]: Thank you, Your Honours. That's helpful. ${ }^{103}$

In this example, Presiding Judge Weinberg de Roca actually performs the very rhythm and tempo of speech that she wants the witness to imitate. Her speech here is so fragmented, so broken up with pauses, that in any other context it would sound nothing short of comedic. Although it probably took about fifteen or twenty seconds to read, at trial the short passage above lasted for over a minute.

It is not just inexperienced witnesses that require coaching. More experienced legal officials regularly forget themselves too:

MADAM PRESIDENT: Slow down, please.

MR NDERITU [counsel for the defence]: I beg your pardon. Yes, I was saying that it is my belief that the Prosecution is in possession of the original passport. And the passport or, at least a copy of it has been used in the previous proceedings before this Tribunal. What we have quite clearly is the referencing by the OTP which is K0073632. I'm sure the Prosecutor would be in a position to assist us in this regard. Thank you.

MR EGBE [counsel for the prosecution]: Your Honour, we do not have the passport of the Accused. And as a matter of fact, the Accused, himself, when he was interrogated by the Dutch police indicated, it is in the written statement, that he destroyed his passport. 
He lost his passport. It's documented. Now, what was provided were copies.

MADAM PRESIDENT: Slowly, please.

MR EGBE: What were provided were photocopies of some pages of that passport. And that was provided, photocopies.

MADAM PRESIDENT: Slow, please. ${ }^{104}$

Or consider the following example from 17 October 2007. Both the witness and the lawyer examining him here speak English, but neither has been leaving sufficient pauses for the interpreters. This time, however, rather than simply mandating that they speak more slowly, Judge Weinberg de Roca asks that they modify their listening practice too - their 'audile technique'. She suggests to counsel for the defence that he wear his headphones in such a way that he can listen to the witness with one ear and the French interpretation with the other. That way, he will know precisely when the interpretation has finished and will be able to determine the rhythm and tempo of his examination accordingly:

MADAM PRESIDENT: Please, we need a pause between question and answer, and we need you to speak slower ... You're not giving the French reporters nor the interpreters an opportunity to catch up ... Please, pause both of - Mr O'Shea, Mr Witness, a pause. Mr O'Shea, I suggest you do what I'm doing, have one - have the headphone on French with one ear, then you can follow.

MR O'SHEA [counsel for the defence]: Okay. Is that number two? All right. That's much better. ${ }^{105}$

If tempo was amongst the most frequent practical concerns during the Bikindi case,${ }^{106}$ matters were certainly not helped by the fact that, for reasons of efficiency, the Tribunal has elected to use the so-called 'relay' system rather than the method employed at Nuremberg. What this means in practice is that, rather than the Kinyarwanda spoken in the trial chamber being translated directly into English, it always goes by way of French first. And obviously this increases the duration of the décalage between original and interpretation considerably - doubles it, in fact.

The system at the ICTR works like this. The interpreters in the French booth translate everything said in English on the floor channel into French. The interpreters in the English booth translate everything said on the floor channel in French directly into English and everything said in Kinyarwanda into English via French relay. The interpreters in the Kinyarwanda booth

\footnotetext{
104 T, 18 September 2006, pp 27-28.

$105 \mathrm{~T}, 17$ October 2007, pp 12-13.
}

106 There are far too many other examples to enumerate here, but one that does deserve a special mention came on October 232007 when Weinberg de Rocca made the following ingenious suggestion. 'Why don't you fill a glass with water and drink every now and then a bit?' she asked of expert witness for the defence Eugene Shimamungu. 'That will make you slow down.' See T, 23 October 2007, p 20. 
translate everything said on the floor channel in English and French into Kinyarwanda as well as everything said in Kinyarwanda on the floor channel into French, both for those who want to listen in French and for the English booth to reinterpret into English (see Figure 2).

French Booth:

- English (floor channel) $\longrightarrow$ French

English Booth:

- French (floor channel) $\longrightarrow$ English

- French* (from Kiny. booth) $\longrightarrow$ English

Kinyanvanda Booth:

- English (floor channel) $\longrightarrow$ Kinyarwanda

- French (floor channel) $\longrightarrow$ Kinyarwanda

- Kinyarwanda (floor channel) $\longrightarrow$ French* (which is then relayed into

English in the English booth)

\section{Figure 2: Interpretation at the ICTR: The Relay System}

By employing the relay system, therefore, the ICTR is able to get by with only three interpreters at any given moment. ${ }^{107}$ This is obviously a major improvement over the Nuremberg system at the level of resources, even if it does produce an additional ritardando in practice. But one thing is abundantly clear. As far as the tempo of international justice is concerned, simultaneous interpretation - and especially when practiced according to the relay system - represents a compromise: a compromise that, since 1945, has now become settled at the level of international legal policy. The great achievement of simultaneous interpretation - and it is a great one - is to render international justice lento ma non troppo: slow, but not too slow. As David Maxwell-Fyfe, the British prosecutor at Nuremberg, put it at the time, the slow pace of examination was "not a high price to pay for ... justice in four voices' ${ }^{108}$ At the ICTR we get it in three.

\section{Simultaneous Interpretation: Justice Has an Accent}

So far we have been concerned with how simultaneous interpretation alters the character of legal eloquence prior to interpretation. Now I want to consider the sound of interpreted speech itself. Strictly speaking, interpreters

\footnotetext{
107 The degree of concentration required for this kind of interpretation is so great that in principle interpreters are supposed to work in shifts of only 30 minutes at a time. In practice, this is not always possible. 
at the ICTR are meant to reproduce the intonation, emphasis, pace and tone of the speech they are interpreting. ${ }^{109}$ This isn't an absolute rule. If a witness is crying as they testify, for instance, interpreters are not meant to mimic their distress - first, because it would be insensitive to do so, and second, because the distress will most likely be sufficiently visually evident in any case. Similarly, when Bikindi sang at trial, which he did on several occasions, interpreters were not expected to do likewise. When one particularly bold interpreter did attempt to sing his interpretation, this was regarded as an amusing anomaly rather than a breach of courtroom etiquette. ${ }^{110}$ Nevertheless, the basic operating principle at the ICTR is that interpreted speech should remain as faithful to the original as possible, in all its various semantic dimensions, prosodic as well as verbal. After all, as Slovenian philosopher Mladen Dolar points out in A Voice and Nothing More, 'intonation can turn the meaning of a sentence upside down; it can transform it into its opposite. A slight note of irony, and a serious meaning comes tumbling down; a note of distress, and the joke will backfire.' ${ }^{111}$ So if a lawyer or a witness employs a sarcastic tone of voice, then that is supposed to be maintained - likewise if they are angry or timid, calm or enthused. Because the first principle of the interpreter, to paraphrase Eric Prenowitz, is that they should 'never really be there'. ${ }^{112}$ They should vanish, in other words, even in the very act of mediation. They should render themselves as transparent, as pure a conduit of the original speech as possible. And in theory at least, this rule applies at the level of sound as well as words.

The question for an acoustic jurisprudence, therefore, is as follows. What are we to make of the fact that, despite the very best efforts of the ICTR's Interpretation Unit, interpreted speech at the Tribunal sounds nothing like uninterpreted speech at all? That when you listen to the recordings of the Bikindi case, you simply can't help but be aware that you're listening to an interpretation? It's not just that so much is clearly being 'lost in translation', as it were. That is a real problem, but it is to be expected. Interpretation, as we have already seen, represents a kind of necessary compromise and its first principle, therefore, is more aspirational

109 According to one paper on the AICC's website entitled 'The Importance of Non-verbal Communication in Professional Interpretation', for example, 'ideally, interpreters should reproduce the same intonation as the speaker'. This is a position which was corroborated in my conversations with interpreters working at the ICTR during my visit in January 2011. See www.aiic.net/ViewPage.cfm/page1662.htm\#51.

110 Counsel for the defence joked as follows: 'If you get acquitted, Mr Bikindi, there's a gentleman in the interpreter's booth who's worthy of review for his singing talent. I'll just inform you.' T, 1 November 2007, p 35.

111 Dolar (2006), p 21.

112 This is an appropriation of Eric Prenowitz's turn of phrase in relation to his translation of Derrida's Mal d'Archive: Une Impression Freidienne into English. It applies equally well, I think, in the context of interpretation. See 'Translator's Note' in Derrida (1996), p 105. 
than realistic. ${ }^{113}$ The really important point from the perspective of an acoustic jurisprudence is that simultaneous interpretation fundamentally changes the sound of legal discourse, and with it the way in which legal actors are required to listen.

To some extent, the fact of interpretation is so palpable acoustically because of the décalage already discussed above. Décalage doesn't just fracture 'original' speech in the courtroom, as we saw in the previous section, it fractures interpreted speech too. Because interpreters are forced to pause so frequently mid-phrase, the emphasis of a sentence is constantly being forced on to the wrong word or syllable, altering its cadence and flow. Interpreted speech thus often sounds lopsided, its metre strange. More than this, however, it has a tendency to sound flat and expressionless. The introduction of simultaneous interpretation into the courtroom doesn't just change the tempo and the rhythm of justice, it gives it a very particular accent too.

If it is possible in principle to discern and 'reproduce' many of the structural elements of prosodic expression, as linguists such as Roman Jakobson have long maintained, ${ }^{114}$ doing so in practice at the ICTR - across languages and cultures, under extreme time pressure and with the additional mediation of the relay system thrown in to boot - is a different matter entirely. And as a result, interpreted speech can sound strangely neutral, lifeless somehow, expressively bland. Occasionally it will even have a faintly irritating quality to it, a timbre and a pitch that grate. As the website of the International Association of Conference Interpreters explains:

The interpreter's voice is an essential working instrument. Interpreters must maintain good control over their voice, timbre, diction and articulation so that listening is pleasant and comfortable for the audience. ${ }^{115}$

Evidently, this is not always an easy task. Even where the interpreter is able to inject a degree of vigour into their speech, it invariably retains a certain

113 For some treatments of court interpreting specifically, see de Jongh (1992); Berk-Seligson (1990); Combs (2010) esp Ch 3. For some excellent general discussion of the problem of translation per se, see Venuti (2000).

114 In an essay published in 1960, Jakobson tells the following rather apposite story. 'A former actor of Stanislavski's Moscow Theatre,' he writes, 'told me how at his audition he was asked by the famous director to make forty different messages from the phrase Segodnja večerum, "This evening," by diversifying its expressive tint. He made a list of some forty emotional situations, then emitted the given phrase in accordance with each of these situations, which his audience had to recognize only from the changes in the sound shape of the same two words. For our research work in the description and analysis of contemporary Standard Russian ... this actor was asked to repeat Stanislavskij's test. He wrote down some fifty situations framing the same elliptic sentence and made of it fifty corresponding messages for a tape recorder. Most of the messages were correctly and circumstantially decoded by Moscovite listeners. May I add that all such emotive cues easily undergo linguistic analysis.' Jakobson (1960), quoted in Dolar (2006), p 21. www.aiic.net/glossary/default.cfm?ID=286. 
mediated quality. You can tell acoustically that the sentiment being conveyed comes second hand. Often it is possible to detect surprise too. You can actually hear the shock in the interpreter's voice - not at the content of what they are interpreting, but at their having been able to interpret it at all. To be an interpreter, after all, is to live on the edge to a degree: in the moment, never quite sure what is coming next but obliged to react instantly no matter what. Interpreted speech, in other words, does not sound natural because it is not natural: it never comes naturally; it is always work.

The upshot of all this is that listening to interpreted speech is difficult. Simultaneous interpretation means that legal actors must learn not only to speak differently, as we saw in the previous section, but to listen differently too. In large part, the listening practice required of participants in a trial at the ICTR simply involves an unusual degree of concentration. This is listening as a form of 'straining', to put it in Jean-Luc Nancy's terms. ${ }^{116}$ In order to participate effectively in contemporary international justice mechanisms, one must learn to listen past the blandness and the lengthy delays, force oneself to make sense of the stumbling cadence, to 'strain toward a possible meaning'. ${ }^{117}$

\section{Conclusion}

This is not a bad note on which to finish. As a community of jurists, we have become deaf to law and to the problem of the acoustic. We must teach ourselves to listen to law: to be attentive, to prick up our ears, to take responsibility for sound in all its juridical forms. This is an activity. Whereas hearing, according to Roland Barthes, is a physiological phenomenon, listening is a psychological act. ${ }^{118}$ It involves 'strain', effort, work. But it is work that is important. Because sound is not indifferent; it has consequences. In the Bikindi case, as we have seen, these consequences were significant, both for the people of Rwanda and for Bikindi himself at trial. Bodies, as Robert Cover put it, are 'on the line'.

There is so much more that could be said. The soundscape of justice is an extremely rich field of inquiry. As far as the ICTR is concerned, there are a couple of issues particularly worth mentioning. First, I would like to have said something here about the changing nature of what French composer, critic and sound theorist Michel Chion has termed the 'audio-visual contract' - the relationship between sight and sound. As Chion puts it, 'we never see the same thing when we also hear', and nor do we 'hear the same thing when we see as well'. ${ }^{19}$ At the ICTR, one particularly interesting development in this respect has been in relation to so-called 'realtime' transcript technologies. ${ }^{120}$ Since 2005, speech at the ICTR has come with subtitles. If

\footnotetext{
116 Nancy (2007), p 6.

117 Nancy (2007), p 6.

118 Barthes (1992), p 245.

119 Chion (1994), p xxvi.

120 Chion (1994), Pt 1.
} 
they wish to, participants are now able to follow a transcript of proceedings made by courtroom stenographers and broadcast to their laptops via infra-red technologies only moments after the words have been uttered. Needless to say, this is a development with significant consequences as far as the phenomenology of justice is concerned. International justice is not just audio-visual, it is becoming increasingly 'audio-textual' too. Second, limited space has forced me to leave out the related questions of broadcasting and the archive altogether. Both the ability of journalists to record live audio of ongoing proceedings for the purposes of radio and webcasts on the one hand, and the Tribunal's ongoing development of a cutting-edge digital audio and audio-video archive on the other, have major implications as far as the soundscape of justice is concerned. The ICTR has tended to frame these issues in terms of 'outreach', but the implications are, I think, broader than that. Audio technologies have become so deeply embedded into juridical practice, both at the ICTR and in relation to international justice mechanisms more generally, that the distinction between the 'trial itself' as a distinct media-spatio-temporal event and its reproduction - later and elsewhere - has begun to break down. ${ }^{121}$ We might think of the ability to broadcast and archive the trial in audio, in other words, not just as two new means of representing or 'recording' judicial proceedings, but as increasingly fundamental parts of the trial as media technology itself.

For now, though, further elaboration along these lines will have to wait. This article, as I said, was intended to be illustrative rather than either comprehensive or expository, its purpose performative: to convince readers that in law sound is worth attending to, and particularly in light of recent developments in relation to audio technology. In his famous essay The Work of Art in the Age of Mechanical Reproduction, Walter Benjamin observed that 'during long periods of history, the mode of human sense perception changes with humanity's entire mode of existence'. ${ }^{122}$ Neither law nor sound is an exception to this rule. As jurists, we would be well advised to pay attention.

\section{References}

\section{Secondary Sources}

Aristotle (1962) Nicomachean Ethics, trans Martin Ostwald, Prentice Hall.

Kelly M Askew (2002) Performing the Nation: Swahili Music and Cultural Politics in Tanzania, University of Chicago Press.

Jacques Attali (1985) Noise: The Political Economy of Music, trans Brian Massumi, University of Minnesota Press.

JL Austin (1962) How to Do Things with Words, Harvard University Press.

Roland Barthes (1992) 'Listening', in The Responsibility of Forms: Critical Essays on Music, Art, and Representation, trans Richard Howard, University of California Press.

\footnotetext{
121 For an elaboration of a similar point - though one that is not overtly concerned with acoustics - see Mohr (2011).

122 Benjamin (1968), p 222.
} 
Walter Benjamin (1968) 'The Work of Art in the Age of Its Mechanical Reproduction', in Illuminations, trans Harry Zohn, Schocken Books.

Lionel Bently and Leo Flynn (eds) (1996) Law and the Senses: Sensational Jurisprudence, Pluto Press.

Susan Berk-Seligson (1990) The Bilingual Courtroom: Court Interpreters in the Judicial Process, University of Chicago Press.

Benjamin F Betts (1931) 'Is This Our Next New Big Business?' American Architect 140.

Pierre Bourdieu (1990) The Logic of Practice, trans Richard Nice, Stanford University Press.

Pierre Bourdieu and Loïc JD Wacquant (1992) An Invitation to Reflexive Sociology, University of Chicago Press.

Michael Bull (2000) Sounding Out the City: Personal Stereos and the Management of Everyday Life, Berg.

Alan Burdick (2001) 'Now Hear This: Listening Back on a Century of Sound' 303(1804) Harper's Magazine 70.

Judith Butler (1997) Excitable Speech: A Politics of the Performative, Routledge.

John Cage (1968) Silence: Lectures and Writings, Calder and Boyars.

Michel Chion (1994) Audio-Vision: Sound on Screen, Columbia University Press.

Cicero (2001) On the Ideal Orator, trans James M. May and Jakob Wisse, Oxford University Press.

Phil Clark (2010) The Gacaca Courts, Post-Genocide Justice and Reconciliation in Rwanda: Justice Without Lawyers, Cambridge University Press.

Nancy Combs (2010) Fact-Finding Without Facts: The Uncertain Evidentiary Foundations of International Criminal Convictions, Cambridge University Press.

Alain Corbin (1999) Village Bells: Sound and Meaning in the $19^{\text {th }}$ Century French Countryside, trans Martin Thom, Columbia University Press.

Robert Cover (1986) 'Violence and the Word' 95 Yale Law Journal 1601.

Sean Cubitt (1998) Digital Aesthetics, Sage.

Jacques Derrida (1996) Archive Fever: A Freudian Impression, trans Eric Prenowitz, University of Chicago Press.

Jacques Derrida (1988) Limited Inc, trans Alan Bass and Samuel Weber, Northwestern University Press.

Jacques Derrida (1989) Of Spirit: Heidegger and the Question, trans Geoffrey Bennington and Rachel Bowlby, University of Chicago Press.

Mladen Dolar (2006) A Voice and Nothing More, MIT Press.

Costas Douzinas (2007) 'The Metaphysics of Jurisdiction', in Shaun McVeigh (ed), Jurisprudence of Jurisdiction, Routledge.

Bob Dylan (1975) Blood on The Tracks, Columbia Records.

Jacques Ellul (1964) The Technological Society, Vintage.

Shoshana Felman (2003) The Scandal of the Speaking Body: Don Juan with JL Austin, or Seduction in Two Languages, trans Catherine Porter, Stanford University Press.

Michel Foucault (1981) The Archaeology of Knowledge, trans AM Sheridan Smith, Routledge.

Francesca Gaiba (1998) The Origins of Simultaneous Interpretation: The Nuremberg Trial, University of Ottawa Press.

Peter Goodrich (1990) Languages of Law: From Logics of Memory to Nomadic Masks, Weidenfeld and Nicolson.

Peter Goodrich (2001) 'Europe in America: Grammatology, Legal Studies, and the Politics of Transmission' 101 Columbia Law Review 2033. 
Paul D Greene and Thomas Porcello (2004) Wired for Sound: Engineering and Technologies in Sonic Cultures, Wesleyan University Press.

Martin Heidegger (1977) The Question Concerning Technology and Other Essays, trans William Lovitt, Harper Perennial.

Roman Jakobson (1960) 'Closing Statement: Linguistics and Poetics', in Thomas A Sebeok (ed), Style in Language, MIT Press.

Frederic Jameson (1988) 'The Vanishing Mediator; or, Max Weber as Storyteller', in Ideologies of Theory, Verso.

Elena M de Jongh (1992) An Introduction to Court Interpreting, University Press of America.

Mark Katz (2010) Capturing Sound: How Technology Has Changed Music, University of California Press.

Patricia Kelly (2008), 'The Quietest Room in the World', www.tcbmag.com/industriestrends/technology/104458p1.aspx.

Donald MacNeil (2002), 'Killer Songs', New York Times, 17 March, www.nytimes.com/2002/03/17/magazine/killer-songs.html?src=pm.

Desmond Manderson (2000) Songs Without Music: Aesthetic Dimensions of Law and Justice, University of California Press.

Marcel Mauss (1979) 'Body Techniques', in Sociology and Psychology: Essays, trans Ben Brewster, Routledge.

Evelyn Moggio-Ortiz (1995) The Interpreters: A Historical Perspective, film produced on the occasion of the 50th anniversary of the United Nations.

Richard Mohr (2011) 'In Between Power and Procedure: Where the Court Meets the Public Sphere', in Marit Paasche and Judy Radul (eds), A Thousand Eyes: Media Technology, Law and Aesthetics, Sternberg Press.

Linda Mulcahy (2010) Justice, Due Process and the Place of Law, Routledge.

Jean-Luc Nancy (2007) Listening, Fordham University Press.

James Parker (forthcoming) Acoustic Jurisprudence.

R Murray Schafer (1968) The Book of Noise, Prize Milburn and Co.

R Murray Schafer (1971) The New Soundscape, Berandol Music and Associated Music Publishers

R Murray Schafer (1973) 'The Vancouver Soundscape' Music of the Environment 2.

R Murray Schafer (1976) The Soundscape: Our Sonic Environment and the Tuning of the World, Destiny Books.

Richard K Sherwin (2011) Visualizing Law in the Age of the Digital Baroque: Arabesques and Entanglements, Routledge.

Jonathan Sterne (2005) The Audible Past: Cultural Origins of Sound Reproduction, Duke University Press.

Bernard Stiegler (1998) Technics and Time, 1: The Fault of Epimetheus, trans Richard Beardsworth and George Collins, Stanford University Press.

Emily Thompson (2004) The Soundscape of Modernity: Architectural Acoustics and the Culture of Listening in America, 1900-1933, MIT Press.

Edgard Varèse (2006) 'The Electronic Medium', in Christoph Cox and Daniel Warner (eds), Audio Culture: Readings in Modern Music, Continuum.

Lawrence Venuti (ed) (2000) The Translation Studies Reader, Routledge.

Cornelia Vismann (2008) Files: Law and Media Technology, trans Geoffrey Winthrop-Young, Stanford University Press. 
Slavoj Žižek (1991) For They Know Not What They Do: Enjoyment as a Political Factor, Verso.

\section{Cases}

Hush-A-Phone v United States, 238 F.2d 266 (DC Cir 1956).

Prosecutor v Bikindi (Judgment) (International Criminal Tribunal for Rwanda), Trial Chamber III, Case No. ICTR-01-72-T, 2 December 2008.

\section{Charters and Statutes}

Charter of the International Military Tribunal, annexed to Agreement for the Prosecution and Punishment of the Major War Criminals of the European Axis, 8 August 1945, 82 UNTS 279.

Statute of the International Criminal Tribunal for Rwanda, SC Res 955, Un SCOR, $49^{\text {th }}$ sess, $3453^{\text {rd }} \mathrm{mtg}$, UN Doc. S/RES/955 (1994), 8 November 1994.

\section{Rules and Reports}

International Criminal Tribunal for Rwanda (1996) First Annual Report of the International Criminal Tribunal for Rwanda.

International Criminal Tribunal for Rwanda (1995) Rules of Procedure and Evidence, 29 June 1995.

\section{Transcripts}

Transcript of Proceedings, Prosecutor v Bikindi (ICTR, 18 September 2006).

Transcript of Proceedings, Prosecutor v Bikindi (ICTR, 19 September 2006).

Transcript of Proceedings, Prosecutor v Bikindi (ICTR, 22 September 2006).

Transcript of Proceedings, Prosecutor v Bikindi (ICTR, 26 September 2006).

Transcript of Proceedings, Prosecutor v Bikindi (ICTR, 27 September 2006).

Transcript of Proceedings, Prosecutor v Bikindi (ICTR, 12 October 2006).

Transcript of Proceedings, Prosecutor v Bikindi (ICTR, 19 February 2007).

Transcript of Proceedings, Prosecutor v Bikindi (ICTR, 24 September 2007).

Transcript of Proceedings, Prosecutor v Bikindi (ICTR, 1 October 2007).

Transcript of Proceedings, Prosecutor v Bikindi (ICTR, 3 October 2007).

Transcript of Proceedings, Prosecutor v Bikindi (ICTR, 5 October 2007).

Transcript of Proceedings, Prosecutor v Bikindi (ICTR, 17 October 2007).

Transcript of Proceedings, Prosecutor v Bikindi (ICTR, 23 October 2007).

Transcript of Proceedings, Prosecutor v Bikindi (ICTR, 31 October 2007).

Transcript of Proceedings, Prosecutor v Bikindi (ICTR, 1 November 2007). 


\section{University Library}

\section{- M M N E R VA A gateway to Melbourne's research publications}

Minerva Access is the Institutional Repository of The University of Melbourne

Author/s:

Parker, J

Title:

The soundscape of justice

Date:

2011-01-01

Citation:

Parker, J. (2011). The soundscape of justice. Griffith Law Review, 20 (4), pp.962-993. https:// doi.org/10.1080/10383441.2011.10854727.

Persistent Link:

http://hdl.handle.net/11343/91762 